\title{
Boundaries of Jewish identities in Contemporary Finland
}

\author{
Preface by Guest Editors
}

DOI: https://doi.org/10.30752/nj.80214

A lthough Finland may often be regarded as distant from Jewish life, the country has its own rich Jewish traditions, and still has its own unique Jewish communities. The current issue of Nordisk judaistik - Scandinavian Jewish Studies fills a significant void in research on Finnish Jewry, by presenting five articles about different aspects of and perspectives on Finnish Jewish life and research. The focus of these works is on the boundaries of Judaism, more specifically on what boundaries members of the local congregations have created over time to maintain their identities in the midst of the predominantly Lutheran yet highly secularized Finnish society. This editorial introduces the history of Finnish Jewry as a background overview to the articles presented in the current issue.

\section{A brief history of Finnish Jewry}

Jewish history in Finland was significantly shaped by the laws of the Swedish kingdom, and later of the Russian Empire. The first Jews arrived in Finland when the country was still part of Sweden (1362-r809). As such, the laws of the country - including those relating to the Jews - were the laws of Sweden. The Swedish Church Law of I686 (Swedish Kyrkio-Lag och Ordning) declared
Evangelical Lutheranism as the state religion: Jews and people of other faiths had the right to gain residence in the country only if they converted to Christianity (Illman and Harviainen 2002: 273). This was the first period of Jewish immigration per se, even if Jews continued to live as Christians after the settlement.

In the I7oos, attitudes towards permanent Jewish immigration were already starting to shift and become more positive, mainly because of the potential economic benefits the Jews could bring to the kingdom (Harviainen 2000: I57-8; Torvinen 1989: I4). The position of Jews in Finland was confined in a code of conduct in I 782 , according to which Jews were not allowed to reside in the current territory of Finland - as they were restricted to live only in certain cities in Sweden (Harviainen 2000: 1 57-8; Torvinen I989: 22-3).

An important period of Jewish immigration to Finland began when the country became a part of the Russian Empire in I809. As a consequence of the defeat of Sweden in the Russian-Swedish war, I 808-9, the Autonomous Grand Duchy of Finland was established within the Russian Empire. Despite this change, the prohibition concerning the settlement of Jews remained (Torvinen I 989: 2 I; Harviainen 2000: I 57).

The first Jews to receive the right to 
settle in Finland without the obligation to undergo conversion to Christianity - the Cantonists - arrived in the country during the first half of the nineteenth century as soldiers serving in the imperial Russian army. The cantonment system of military service was put into effect by Tsar Nicholas I (ruled I 825-55), who made the cantonist school system for the military education compulsory for Jewish minors, in order to assimilate them into Russian society. The Cantonists were young Jewish boys who were forcibly torn away from their parents and families, educated in Russian schools and compelled to join the Orthodox Church. The statute of 1858 allowed them and their families to stay in Finland. Jewish soldiers continued to settle in the territory of Finland, even after the cantonist system was abolished in the I 85 os, up until r9 7 , when Finland gained independence. The decree of I 869 decided on the occupations open to Jews, which came to be limited mainly to dealing in clothing and other hand-made materials at narinkkatori ${ }^{1}$ - at the marketplace (Harviainen 2000 : I 58; Illman and Harviainen 2002: 274-5; Harviainen I 998: 294).

According to the census of 1870 , the number of Jews amounted to 460 people, the majority of them living in Helsinki (Torvinen 1989: 28-3I). In 1889, the Finnish Senate issued a letter to the governors of Finland, which guaranteed permission to Jews and their families - who were mentioned by name - to reside in Finland in specific towns. These towns were Helsinki, Turku, Tampere, Vyborg (Viipuri), Hamina, Sordavala (Sortavala), Suistamo, Impilahti, Kuopio and Vaasa (Vasa). These permits were granted for six months at a time. Persons who committed a

1 From the Russian на рынке (na rynke), 'on the market'. The site is currently occupied by the Scandic Hotel Simonkenttä, on Simonkatu, Helsinki. crime were sent back to Russia. Children of the Jews who were granted these rights were only allowed to stay in Finland until they turned eighteen. New Jews were not allowed to stay in the country. Their activities were still limited mainly to dealing in clothing. This decree was in force until r9 8 (Illman and Harviainen 2002: 275-6).

Already in the early period of the settlement of the Jews in Helsinki, Jewish children started to attend the local Swedish and Russian schools of the town, where they naturally did not receive traditional Jewish education (Muir 2004: 84-96). According to some sources Finnish Jews were influenced by a modern world-view adopted during the time they spent in military service. Many of them were indifferent to providing Jewish education to their children, and not all of them lived to the standards of strict Orthodoxy (ibid. 3). In I 906, the current building of the synagogue in the centre of Helsinki was consecrated, and a new Jewish school opened on its first floor (ibid. 92), which then spurred some members of the congregation to challenge the rabbinic authorities (Muir and Tuori in the current issue). The synagogue of Vyborg was completed in г9г, and that of Turku was consecrated in I9I 2 (Fenno-Judaica nd).

\section{Finnish Jews gain citizenship}

Even though the discussions about the rights of the Jews began in the Diet of 1872 , Jews were granted full civil rights only after Finland had gained independence in I9I7 (Harviainen 2000; Weintraub 20 I 7; Reijonen I980). On 22 December I 9 I 7, the Parliament approved an act concerning the Jews, which was promulgated on I 2 January I9I 8 , stating that Jews were granted civil rights and could become Finnish nationals. Finland was the last country in Europe to grant full rights 
to its Jewish citizens (Illman and Harviainen 2002: 276; Weintraub 20 I 7: I I 7). A few years later, the freedom of religion in Finland was implemented by the Freedom of Religion Act of 1922 (UVL 267/r922). The law provided all citizens the right to practise their religion in public and private. It also granted the right not to belong to any religious community, and addressed the question of children whose parents belonged to different religious congregations or were not members of any at all (Kaila I923) - which as the articles in this issue highlight, became an influencing factor in the local congregations (Czimbalmos in the current issue).

Between and during the World Wars, assimilation was vigorous in the Jewish Community in Helsinki. Jewish parents often decided not to send their children to the Jewish schools, and the number of intermarriages started to rise in the community from the early i93os. Herman Morath, a Yiddish writer from Latvia, gave an insight into the life of the Jewish Community of Helsinki during the I920s. He mentioned that the community was characterised by assimilation, intermarriages and secularisation. Many sources state that among the Jewish communities in Finland the community of Helsinki was the least observant of Jewish practices. Moreover, compared to the Yiddish-speaking Jewish Community of Turku, many of its members preferred using Swedish. In the I 93 os, the most used language of the Helsinki congregation and its institutions was mostly Swedish, and most of the members of the community reported Swedish as their mother tongue, though many of them were fluent in Yiddish. In Vyborg, Yiddish remained the official language of the congregation until the Second World War (Muir 2004: 2 I 4).

In 1920 , there were 1468 Jews residing in Finland. Of these, ro97 were born in Finland. As Finnish became the main language of the country, Jews also started to become Finnish speakers. In I 925 , the number of Jews rose to I699, in I 930 to 1728 and during the Winter War in 1939 to I793. Three-fifth of the Jews lived in Helsinki, one-fifth in Turku and one-fifth in Vyborg (Weintraub 20I7: I I7). There was also a small Jewish Community in Hämeenlinna, and later, in I 948, the Jewish Community of Tampere was established (ibid. I I6).

\section{The Second World War}

During the Winter War (1939-40), Finnish Jews fought alongside non-Jewish compatriots. In early I94I, the Finnish government believed that it was unlikely that Finland would stay neutral: during the Continuation War (I94I-4), in which Finnish Jews also took part, Finland and Nazi Germany were co-belligerents. ${ }^{2}$ On 6 November I942, a German transport vessel left the harbour of Helsinki with twenty-seven civilians, including eight Jews, who were deported from Finland. Only one of them survived the war. 'Those eight' have become the symbol of Finland's involvement in the Shoah. By the time the deportations from Finland gained public attention, the Finnish authorities had already been deporting Jews - both foreign civilians and Soviet prisoners-of-war - to the German authorities. It has even been suggested that while the Finnish authorities may not have attempted to seek the death of Jewish deportees per se, the Finnish state police most definitely acted on antisemitic impulses (Silvennoinen 2013: 213).

2 For a recent contribution to this discussion, see Mats Deland's review in this issue of Lars Westerlund's report The Finnish SS-volunteers and Atrocities against Jerws, Civilians and Prisoners of War in Ukraine and the Caucasus Region 1941-1943. 


\section{Jewish history after the War}

Vyborg was lost to the Soviet Union in 1944. Its community was evacuated to Tampere, but many of the families that were taken to Tampere settled in Helsinki instead (Ekholm 2013: 34). The Vyborg Jewish community stopped operating completely in 1958 .

During the Arab-Israeli war of I948-9 (the Israeli War of Independence), twentynine Finnish Jews fought as volunteers for the State of Israel. After the establishment of Israel, as a result of immigration to the country, the size of Finnish Jewry decreased (Torvinen I989: 175-7). At this point, there were three Jewish communities operating in Finland, the biggest being the one in Helsinki, and the two smaller ones in Turku and Tampere.

These communities went through various changes over time. In Helsinki, discussions about preventing the secularisation of the community and the assimilation of its members appeared in the debates of the congregation already in the I 95 os. As a possible solution to these issues, the Jewish Community of Helsinki established the Jewish nursery school for children between the ages of three and seven in r953. The community had already established its own school in I9r8, where the teaching of Hebrew and the basics of the Jewish religion were parts of the curriculum (Weintraub 20 I 7: I I 8). In terms of religious life, the Jewish Community of Helsinki often faced issues when searching for a rabbi for the community (Muir and Tuori in the current issue). After the Six Day War (5-io June 1967$)^{3}$ and the Yom Kippur War (6-26 October I973), ${ }^{4}$ the perception of Israel and

3 Also known as Day War, June War, I 967 Arab-Israeli War or Third Arab-Israeli War.

4 Also known as Ramadan War, October War or 1973 Arab-Israeli War.
Jews started to change in Finnish society, and in 1977 a security alarm was placed on the Jewish Community of Helsinki (ibid. I I 9). In the same year, the Jewish Community of Helsinki facilitated the conversion of a large number of people to Judaism (Czimbalmos in the current issue). In the early r 980 , owing to the small number of community members, the Jewish Community of Tampere ended its activities (Harviainen 1998: 297; Weintraub 201 7: I I 9). During the last part of the twentieth century, the membership base of the communities was decreasing. In I986, the number of people registered in the Jewish Community of Helsinki was 1092 , in that of Turku 217 (Torvinen I989: 21 I). These two communities were highly affected by continuous secularisation, changes in Finnish laws (such as banning circumcision and forbidding kosher slaughter - for the latter see Pataricza in the current issue). Moreover, the economic status of local Jewry also changed over the decades: starting as dealers in clothing, most Jews now went on to gain degrees in higher education (Ekholm 2013). In the early I 990s, the congregations were affected by the influx of Jews from the Soviet Union. In the past two decades, immigration to the community, as well as to Finland in general, has become a more common phenomenon, which has also had an impact on the community both in terms of its traditions and the languages used (Weintraub 201 7). Today, it is very hard to estimate the number of Jews living in Finland. There are approximately I 300 members registered in the two congregations according to their admiministrative personnel. This includes members living abroad.

\section{Perspectives on Jewish identity highlighted in this issue}

Previous research on Jews in Finland has mostly addressed the history or the economic 
status of local Jewry (Torvinen I 989; Harviainen and Illman I998; Harviainen 2000; Muir 2014; Ekholm 2013) and to Second World War and Holocaust studies (Muir and Worthen 2013). Some copious studies of the local community's culture and traditions have been published, in Finnish and Swedish, by the community itself (e.g. Kantor et al. 2006; Weintraub 20I7), as well as certain works on the cultural and linguistic diversity of the local congregations (Muir 2004; Ekholm et al. 2016). There are also a few MA theses written on subjects relating to Finnish Jewry (e.g. Larsson 2014; Czimbalmos 20r6; Shaul 20I7; Zaitsev 2019). Some short encyclopaedia entries are also available on Jews in Finland (e.g. Lundgren 2006).

The current issue includes five articles dealing with Finnish Jewry. The first two analyses deal closely with the Jewish Community of Helsinki, from a historical point of view, whereas the last three approach the broader topic of Finnish Jewry from more contemporary and theoretical perspectives.

The issue opens with an article pertaining to aspects of the history of Finnish Jewry which have not been researched systematically hitherto. In the first article, 'The golden chain of pious rabbis: the origin and development of Finnish Jewish Orthodoxy', Simo Muir and Riikka Tuori set out the historical basis for research into contemporary Finnish Jewry by looking into the succession of rabbis in the Jewish Community of Helsinki. They demonstrate how the traditions of the congregation were formed by these leading figures of the community between I 867 and I 982 , thus illuminating the uniqueness of Finnish Jewry today.

The second article, by Mercédesz Czimbalmos, 'Laws, doctrines and practice: a study of intermarriages and the ways they challenged the Jewish Community of Helsinki from I930 to I970', presents two empirical, historical examples of religious and administrative practices that emerged in the congregation as results of the rising number of intermarriages, highlighting some of the matters that arose in the congregation after the Freedom of Religion Act was implemented in 1922 .

In her article 'Intersections of gender and minority status: perspectives from Finnish Jewish women', Elina Vuola applies the concept of intersectionality, arguing that applying it as a theoretical framework may illuminate some aspects of Jewish diaspora identities. She concludes that diaspora identities become clearly visible especially in issues related to gender among the members of the Finnish Jewish minority.

Drawing on the data derived from Vuola's project, 'Embodied Religion: Changing Meanings of Body and Gender in Contemporary Forms of Religion in Finland' (Vuola 20I8), collected during her research, Dóra Pataricza focuses on the Finnish Jewish food culture in her article 'Challahpulla: where two wor(1)ds meet'. The article highlights the rapid changes over the past thirty years in Finnish-Jewish cuisine, reflecting the difficulty of purchasing kosher ingredients in Finland. Pataricza concludes that food is often one of the strongest links to the Ashkenazi Jewish roots among women in the local congregations.

Finally, Ruth Illman presents the ethnographically driven multi-method research perspective of vernacular religion in researching Judaism in Finland. She analyses the potential to contribute to the theoretical advancement of Jewish studies by researching Finnish-Jewish everyday lives. She exemplifies her theoretical and methodological considerations by introducing a recently initiated research project focusing on vernacular Judaism in Finland, 'Boundaries of Jewish Identities in Contemporary Finland', to 
which most of the researchers contributing to this issue are linked.

These five articles aim to address topics that have so far never been studied, and they investigate matters that are part of the everyday lives of local Jews and their communities. Thus, the current issue fills a significant void in the research of Jewish studies in general, and Finnish Jewry in particular.

For the transliteration of Hebrew, Aramaic and Yiddish terminology, the authors have adopted the most commonly used English method. Rarely used foreign words are italicised and transliterated according to the guidelines of the SBL Handbook of Style.

The current issue concludes with a review section. Firstly, the Swedish historian Mats Deland comments and reflects upon the recently published report by Lars Westerlund, 'The Finnish SS-volunteers and atrocities r 94I-3'. The report, which was commissioned by the president of Finland, Sauli Niinistö, was released earlier this spring. Thereafter, Pekka Lindqvist reviews a recently published anthology of the Jewish School of Helsinki on the occasion of its centenary. This issue closes with two contributions by Flemming Ravn: a review of a recently published Hebrew grammar book and an obituary of Amos $\mathrm{Oz}$.

MERCÉDESZ CZIMBALMOS and DÓRA PATARICZA
Mercédesz Czimbalmos

is a doctoral student in comparative religion at Åbo Akademi University. Her background is in Jewish studies, comparative religion, cultural studies and Japanese studies. Her research interests includes contemporary Judaism, and intercultural and interreligious encounters. Currently, she is working on her doctoral dissertation, studying intermarriages in Finnish Jewish communities. Her main focus is on discourses around intermarriage and conversion among within Finnish Jewry.

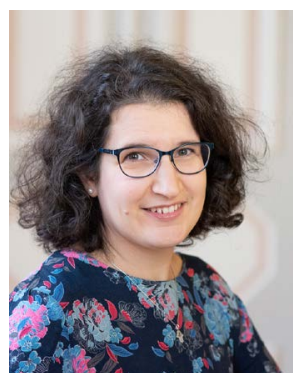

Dóra Pataricza is currently working in a research project led by Ruth Illman, entitled 'Boundaries of Jewish Identities in Contemporary Finland', on a case study entitled 'Foodways'. Her project focuses primarily on how boundaries are drawn up and crossed in Jewish-Finnish cuisines, where culinary traditions are shaped by influences from different times, cultures, geographical regions and traditions. Pataricza is a Doctor of Classical Philology from the University of Debrecen, Hungary.

\section{Bibliography}

Czimbalmos, Mercédesz, 2016. 'How do they Jew? Identity and Religiosity in the Jewish Community of Helsinki', unpublished MA thesis, Department of World Culture, Faculty of Arts, University of Helsinki

Ekholm, Laura, 201 3. Boundaries of an Urban Minority: The Helsinki Jewish Community from the End of Imperial Russia until the 1970s (Department of Political and Economic Studies, University of Helsinki)

Ekholm, Laura, Simo Muir, and Oula Silvennoinen, 2016. 'Linguistic, cultural and historyrelated studies on Jews in Finland: a look into the scholarship in the twenty-first century', Nordisk judaistik - Scandinavian Jewish Studies, 27(I), pp. 43-57, doi: <https://doi. org/10.30752/nj.67605>

Fenno-Judaica, an online collection of the history of the Finnish Jews, <http://fennojudaica. jchelsinki.fi/> (accessed 3.4.201 9) 
Harviainen, Tapani, I 998. 'Juutalaiset Suomessa', Juutalainen kulttuuri, ed. Tapani Harviainen and Karl-Johan Illman (Helsinki, Otava), pp. 29I-304

2000. 'The Jews in Finland and World War II', Nordisk judaistik - Scandinavian Jewish Studies, 2 I, pp. I 57-66, doi: <https:// doi.org/ro.30752/nj.69575>

Harviainen, Tapani, and Karl-Johan Illman, I 998. Juutalainen kulttuuri (Helsinki, Otava)

Illman, Karl-Johan, and Tapani Harviainen, 2002. Judisk historia (Åbo Akademi)

Kaila, Erkki, I923. Uskonnonvapauslaki ynnä siihen liittyvät lait ja asetukset (Helsinki, Otava)

Kantor, Dan, Mindele London-Zweig, and Simo Muir, 2006. LeChaim! Kuvia Suomen juntalaisten historiasta. Images from the History of Jerws in Finland (The Jewish Community of Helsinki)

Larsson, Julia, 20 4 4. Juutalaisuus on sitä, että lukee ensimmäisenä lehdestä juutalaisia koskevat uutiset. Suomen juutalaisten nuorten aikuisten käsityksiä omasta juutalaisuudestaan', unpublished MA thesis, Faculty of Educational Sciences, University of Helsinki

Lundgren, Svante, 2006. 'Jews in Finland', Encyclopedia of the Jerwish Diaspora, ed. Avrum Ehrlich (Santa Barbara CA, ABC Clio), pp. I07 I-6

Muir, Simo, 2004. Yiddish in Helsinki: Study of a Colonial Yiddish Dialect and Culture (Helsinki, Finnish Oriental Society)

Muir, Simo, and Hana Worthen (eds), 2013. Finland's Holocaust: Silences of History (London, Palgrave Macmillan)

Reijonen, Mikko, I980. Uskonnonvapauden toteuttaminen Suomessa vuosina 1917-1922 (Helsinki, Suomen Kirkkohistoriallinen Seura)

Shaul, Daniel, 20 I 7. 'Ympärileikkaus juutalaisuudessa. Juutalaisen identiteetin kulmakivi?' unpublished MA thesis, Faculty of Educational Sciences, University of Helsinki

Silvennoinen, Oula, 2013. "Beyond "those eight": deportations of Jews from Finland I 94 II 942', Finland's Holocaust: Silences of History, ed. Simo Muir and Hana Worthen (London, Palgrave Macmillan), pp. I94-2 I7

Torvinen, Taimi, I 989. Kadimab: Suomen juutalaisten historia (Helsinki, Otava)

UVL $267 /$ i 2 2. Uskonnonvapauslaki, $267 /$ i $922,<$ http://www.finlex.fi/fi/laki/ alkup/I $922 /$ I $9220267>$ (accessed 3.4.2019)
Vuola, Elina, 201 8. Jerwish Women in Finland, project website, <http://blogs.helsinki.fi/ embodied-religion/vuola-jewish/> (accessed 7.9.2018)

Weintraub, Daniel, 20 I7. 'Juutalaiset ja juutalaisuus Suomessa', Monien uskontojen ja katsomusten Suomi, ed. Ruth Illman, Kimmo Ketola, Riitta Latvio and Jussi Sohlberg (Kuopio, Kirkon tutkimuskeskus), pp. I I6-26

Zaitsev, Kira, 20 I. 'Conversion to Judaism: Finnish Gerim on Giyur and Jewishness', unpublished MA thesis, Department of Languages, University of Helsinki 